University of Nebraska - Lincoln

DigitalCommons@University of Nebraska - Lincoln

USGS Staff -- Published Research

US Geological Survey

2015

Relative importance of phosphorus, invasive mussels and climate for patterns in chlorophyll a and primary production in Lakes Michigan and Huron

David M. Warner

USGS Great Lakes Science Center, Ann Arbor, MI

Barry M. Lesht

University of Illinois at Chicago

Follow this and additional works at: http://digitalcommons.unl.edu/usgsstaffpub

Warner, David M. and Lesht, Barry M., "Relative importance of phosphorus, invasive mussels and climate for patterns in chlorophyll a and primary production in Lakes Michigan and Huron" (2015). USGS Staff -- Published Research. 866.

http:// digitalcommons.unl.edu/usgsstaffpub/866

This Article is brought to you for free and open access by the US Geological Survey at DigitalCommons@University of Nebraska - Lincoln. It has been accepted for inclusion in USGS Staff -- Published Research by an authorized administrator of DigitalCommons@University of Nebraska - Lincoln. 


\title{
Relative importance of phosphorus, invasive mussels and climate for patterns in chlorophyll a and primary production in Lakes Michigan and Huron
}

\author{
DAVID M. WARNER* AND BARRY M. LESHT ${ }^{\dagger}$ \\ *USGS Great Lakes Science Center, Ann Arbor, MI, U.S.A. \\ ${ }^{\dagger}$ Department of Earth and Environmental Sciences, University of Illinois at Chicago, Chicago, IL, U.S.A.
}

\section{SUMMARY}

1. Lakes Michigan and Huron, which are undergoing oligotrophication after reduction of phosphorus loading, invasion by dreissenid mussels and variation in climate, provide an opportunity to conduct large-scale evaluation of the relative importance of these changes for lake productivity. We used remote sensing, field data and an information-theoretic approach to identify factors that showed statistical relationships with observed changes in chlorophyll a (chla) and primary production (PP). 2. Spring phosphorus (TP), annual mean chla and PP have all declined significantly in both lakes since the late 1990s. Additionally, monthly mean values of chla have decreased in many but not all months, indicating altered seasonal patterns. The most striking change has been the decrease in chla concentration during the spring bloom.

3. Mean chlorophyll a concentration was $17 \%$ higher in Lake Michigan than in Lake Huron, and total production for 2008 in Lake Michigan $\left(9.5 \mathrm{tg} \mathrm{year}^{-1}\right.$ ) was 10\% greater than in Lake Huron

(7.8 $\operatorname{tg}$ year $^{-1}$ ), even though Lake Michigan is slightly smaller (by 3\%) than Lake Huron. Differences between the lakes in the early 1970s evidently persisted to 2008 .

4. Invasive mussels influenced temporal trends in spring chla and annual primary production. However, TP had a greater effect on chla and primary production than did the mussels, and TP varied independently from them. Two climatic variables (precipitation and air temperature in the basins) influenced annual chla and annual PP, while the extent of ice cover influenced TP but not chla or primary production. Our results demonstrate that observed temporal patterns in chla and PP are the result of complex interactions of $\mathrm{P}$, climate and invasive mussels.

Keywords: chlorophyll, climate, oligotrophication, primary production

\section{Introduction}

Inland waters, including lakes, are globally important as part of the carbon cycle (Dean \& Gorham, 1998; Alin \& Johnson, 2007), and burial of organic carbon in lakes is believed to be almost half that in the oceans (Dean \& Gorham, 1998). Even though large lakes $\left(>500 \mathrm{~km}^{2}\right)$ have a collective basin area $<1 \%$ of the oceans, they sequester $6-13 \%$ as much organic carbon as is retained by the oceans (Alin \& Johnson, 2007). As a result, the trophic status and carbon fixation/sequestration rates of large lakes are important on a global scale. The study of the trophic status of the Laurentian Great Lakes began in earnest in the 1960s with concerns about eutrophication (Beeton, 1965). Vollenweider, Munawar \& Stadelman (1974) used estimates of primary production (PP) to assign the Great Lakes to trophic classes and described all of them as having been enriched by humans. In some areas of the lakes, eutrophication during the 1950s-1970s led to hypolimnetic dissolved oxygen concentrations sufficiently low to affect deleteriously fish and benthic invertebrates (Colby et al., 1972; Madenjian et al., 2011). Following the Great Lakes Water Quality Agreement (GLWQA, 1978), phosphorus loading declined and water quality in many areas improved gradually through the late 1990s. More recently, there has been a more rapid

Correspondence: David Warner, USGS Great Lakes Science Center, 1451 Green Road, Ann Arbor MI 48105, U.S.A. E-mail: dmwarner@usgs. gov 
trend towards re-oligotrophication of some lakes (Evans, Fahnenstiel \& Scavia, 2011; Barbiero, Lesht \& Warren, 2012), with some researchers reporting a convergence in the trophic status of lakes Michigan, Huron and Superior in the last decade (Barbiero et al., 2012). These changes have probably been important in the carbon cycling role of these lakes and may have caused the reduced fish biomass in some of the lakes (Riley et al., 2008).

While it is apparent that the gradual reduction in productivity between the 1970s and 1990s in lakes Michigan and Huron resulted from management efforts (reduced P loading, Evans et al., 2011; Pothoven \& Fahnenstiel, 2013; Rowe et al. 2015), more rapid, further reductions in chlorophyll a (chla) and PP reductions were observed between the late 1990s and 2003. This has been widely attributed to filtering by invasive mussels (initially Dreissena polymorpha, then D. rostriformis bugensis; Fahnenstiel et al., 2010; Vanderploeg et al., 2010), a conclusion also echoed in other studies (Kerfoot et al., 2010; Evans et al., 2011). However, although direct filtering by invasive mussels probably reduced spring chla and PP, it was unlikely to be responsible for reduced chla or PP in the summer (Rowe et al., 2015). Rowe et al. (2015) concluded that the impact of filter feeding by invasive mussels, and phytoplankton growth, was influenced by vertical mixing and thermal stratification, which are in turn regulated by meteorological conditions. The work of Rowe et al. (2015) demonstrated that, unlike decreased $\mathrm{P}$ loading, filtering by invasive mussels can cause the observed rapid decreases in spring chla concentrations but that this capacity is buffered by climate.

Climatic variation has been found to influence the magnitude of chla or PP (O'Reilly et al., 2003) in at least one large lake and probably influences the phenology of phytoplankton biomass, chla and PP in many lakes (Shimoda et al., 2011). Before the widespread effects of invasive mussels on Lake Michigan, a number of studies proposed a climatic influence on productivity and nutrient concentrations in the Great Lakes. Rodgers \& Salisbury (1981) and Scavia et al. (1986) postulated that extended ice cover in winter led to reduced nutrient concentrations and productivity. Supporting this idea, Nichols (1998) found that spring TP concentration in Lake Huron was negatively correlated with maximum $\%$ ice cover. The likely mechanism was a reduction of sediment resuspension in periods of ice cover, which is plausible given the large quantities of nutrients known to be resuspended by turbulent mixing (Brooks \& Edgington, 1994; Eadie et al., 2002). Turbulent mixing events have been a regular occurrence in Lake Michigan and are regulated by climate (Schwab et al., 2006), and one such event has been identified as having had a large impact on annual primary production in Lake Michigan (Lesht et al., 2002).

While many efforts have been made to describe changes in chla and PP in lakes Michigan and Huron, none has examined simultaneously data from more than one lake for evidence of the roles of $\mathrm{P}$ loading and concentration, invasive mussels and climate. This was the aim of our study, in which we used 11 years of satellitederived estimates of primary production and chlorophyll $a$, nutrient-based indicators (spring turnover TP and phosphorus loading), several measures of climate, and invasive mussel density to assess trends in chla and primary production and to identify factors that influenced them in lakes Huron and Michigan over the period 1998-2008. We hypothesised that recent decreases in chla and primary production were the result of a suite of factors, including climate, nutrient concentrations and filtering by invasive mussels, rather than invasive mussels alone. Further, given previous observations, we hypothesised that ice cover negatively influenced both chla and PP.

\section{Methods}

\section{Chlorophyll $a$ and primary production}

Chlorophyll a and PP were estimated from satellite data for each day in the period 1998-2008. Satellite estimation of chla is based on the principle that the wavelengths of light scattered by water vary with the amount of chlorophyll-containing phytoplankton present (Morel \& Prieur, 1977; Lesht, Barbiero \& Warren, 2013). Sensors on satellites can use this property to estimate chla concentrations. Estimation of PP with satellite data then combines this information with (satellite-based) estimates of water temperature and clarity, and light intensity (Behrenfeld \& Falkowski, 1997a,b). With the exception of 156 days in 2008 for which there were no data, estimates were derived from SeaWiFS data. For those days in 2008 without SeaWiFS data, we estimated SeaWiFS chla and primary production values using a regression relationship between MODIS chla and primary production and SeaWiFS chla and primary production for the period 2003-2007. Both chla production and primary production from these two sources were highly correlated, with MODIS predicting somewhat higher values of both.

Raw satellite data (level 1, L1) were obtained from the NASA Ocean Color Web Archive (http://www.ocean color.gsfc.nasa.gov/cms/). The L1 scenes were extracted

(C) 2015 John Wiley \& Sons Ltd, Freshwater Biology, 60, 1029-1043 
to include only those scenes that covered at least $75 \%$ of the target lake (Huron or Michigan). Processing to level two (L2) was conducted with the 12gen module of SeaDASv6.1 (Baith et al., 2001) and included atmospheric correction (iterative model using near infrared), geolocation, calibration and quality control screens. Pixels that failed the SeaDAS quality control criteria (ATMFAIL, HIGLINT, HILT, STRAYLIGHT, CHLFAIL, NAVFAIL) were flagged, and areas of cloud and ice were masked. An output file was generated with standard products including chla, kd490, photosynthetically active radiation (PAR) and remote sensing reflectance at several wavelengths. The standard NASA band ratio algorithm (OC4v6) was used for the chlorophyll estimation. This approach uses the greater of reflectance band ratios (443 nm: $555 \mathrm{~nm}, 489 \mathrm{~nm}$ : $555 \mathrm{~nm}$ or $510 \mathrm{~nm}: 555 \mathrm{~nm}$ ) as input to a polynomial function relating the ratio to chla. Several studies have demonstrated the utility of the band ratio algorithm for estimating chla concentrations in the Great Lakes (Lesht et al., 2013).

Each L2 file was passed through the 13bin module of SeaDAS to create files with slightly reduced resolution $(2 \mathrm{~km})$ of standard equal-area bins. The binned files included only data for those bins that have passed the quality control screens. The equal-area bins were a prerequisite to temporal compositing required to construct a complete daily data set. We used temporal compositing to create a spatially complete daily file for each lake and variable. Although there are several possible algorithms for this process, we used a modification of the method used by the National Oceanographic and Atmospheric Administration (NOAA) Great Lakes Environmental Research Laboratory (GLERL) to produce the Great Lakes Surface Environmental Analysis (GLSEA) temperature product (Schwab, Leshkevich \& Muhr, 1999). This method is based on a centred moving average that weights nearby observations most heavily.

The primary production estimates were generated using what Behrenfeld \& Falkowski (1997a) classified as a depth-integrated model (DIM). More specifically, we used a vertically generalised production model (VPGM; Behrenfeld \& Falkowski, 1997b) with Eppley's (1972) temperature-dependent growth function. This approach uses inputs of chla concentration, water temperature, PAR and euphotic zone depth (z_eu). We used the daily interpolated satellite chla and PAR fields for these estimates. Daily z_eu was estimated from the satellite kd_490 product using Morel et al.'s (2007) method, in which $z_{-}$eu is estimated from $z_{-}$eu $=-(\ln (0.01) / \mathrm{kpar})$ where $\quad k p a r=0.0864+(0.884 * k d 490)-0.00137 /$ $\mathrm{kd} 490)$. We used daily sea surface temperature fields
(SST) obtained from NOAA-GLERL GLSEA estimates transformed to the same grid used for the other satellite data. While the choice of primary production model can influence results, Behrenfeld \& Falkowski (1997a) argued that the primary sources of variation among or within models were the estimate of chla and the maximum photosynthetic rate $p_{o p t}^{b}$, which we estimated from water temperature. Although Lesht et al. (2002) also used a temperature-based primary production estimator, other recent attempts to model primary production in the Great Lakes have been based on light intensity methods for estimating $p_{o p t}^{b}$ (e.g. Fahnenstiel et al., 2010; Shuchman et al., 2013). Because our method varied from other recent efforts to estimate primary production from satellite data in Lake Michigan (Shuchman et al., 2013), we evaluated the comparability of our PP estimates to previous estimates made for Lake Michigan in the period 1998-2008, including those from in situ estimates of parameters (Fahnenstiel et al., 2010) and satellite estimates (Shuchman et al., 2013). Both of these studies used some version of the Great Lakes Primary Production Model (GLPPM; Fee, 1969). To facilitate comparison of our primary production estimates and those from these other studies, we calculated monthly mean satellitederived primary production at the two locations for each month for which Fahnenstiel et al. (2010) provided estimates in 1998, 2007 and 2008. We used linear regression to assess the relationship between the two estimates for the same locations and dates. We compared our results to the data in Fahnenstiel et al. (2010) at two temporal scales: one including all years $(1998,2007,2008)$ presented in Fahnenstiel et al. (2010) and one for only those years in which Shuchman et al. (2013) also made estimates (2007-2008). There was a significant statistical relationship $\left(r^{2}=0.71, \quad P \ll 0.001, \quad N=23 ; \quad\right.$ Fig. 1$)$ between our monthly estimates of primary production and those in Fahnenstiel et al. (2010). The slope ( $\pm 95 \mathrm{CL}$, $0.86 \pm 0.26)$ was not significantly different from one, and the intercept $(8.7 \pm 160)$ was not different from zero. We also found a significant statistical relationship between our estimates and those in Shuchman et al. (2013) from 2007 and $2008\left(r^{2}=0.66, P \ll 0.001, N=18\right.$; with the slope and intercept not different from one and zero, respectively). Regression with the Fahnenstiel et al. (2010) estimates as the response variable and the satellite-derived primary production estimates from Shuchman et al. (2013) as the predictor also resulted in a significant relationship but with much lower explanatory power than our model estimates $\left(r^{2}=0.49, P=0.002\right.$, $N=16)$ and with a slope that was significantly less than one $(0.61 \pm 0.35)$. The intercept of this relationship was 
not different from zero $(P>0.05)$. Based on these analyses, we conclude that our primary production estimates are similar to estimates derived from periodically measured in situ parameters and the GLPPM, as used by Fahnenstiel et al. (2010).

\section{Climate and physical variables}

A number of climatic indices as well as physical variables were available for use as potential predictors of chla and primary production [e.g. the North Atlantic Oscillation (NAO), El Nino-Southern Oscillation (ENSO), air temperature, precipitation rates, cloud cover]. Although linkages between climate indices and the Great Lakes have been identified (Nichols, 1998; Wang et al., 2012), the linkages still are relatively poorly understood. While it is highly likely that these indices and teleconnections with the Great Lakes influence the lakes in a variety of ways, we focussed on more mechanistic relations with climatic variables rather than climate indices like ENSO. Our initial list of climate measures included variables that have been linked to either chla or primary production in previous studies. These included date of onset of thermal stratification (strat), annual mean air temperature in the drainage basin of each lake (or spring mean air temperature), annual mean sea surface temperature (SST, or January-May surface temperature), annual precipitation in the basin of each lake (or spring precipitation) and the extent of ice cover. The date of onset of thermal stratification and JanuaryMay surface temperature were determined from a model of evaporation and thermal flux developed for the Lau-

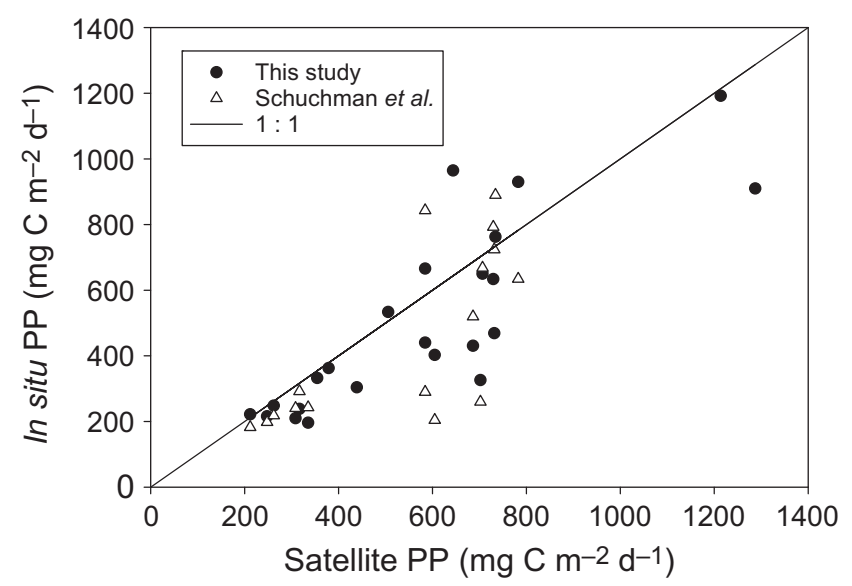

Fig. 1 In situ/model estimates of primary production versus satellite-estimated primary production for the same month and location. In situ model estimates were from Fahnenstiel et al. (2010). Also shown are satellite-derived estimates from Shuchman et al. (2013). rentian Great Lakes by NOAA-GLERL (Croley, 1995). Using daily inputs of air temperature, wind speed, humidity and cloud cover from around the Great Lakes basin, the model generates daily lakewide mean temperature at depth in 1-m increments from the lake surface to the bottom. We identified the onset date of thermal stratification as the day after which the water temperature stayed above $4^{\circ} \mathrm{C}$. Mean SST was derived from the GLSEAs. Annual mean and January-May air temperature and precipitation in the basins were obtained from the NOAA-GLERL monthly hydrological data (http:// www.glerl.noaa.gov/ftp/publications/tech_reports/ glerl-083/UpdatedFiles/), which provide data to update those included in Quinn \& Kelley (1983). These climate and physical variables were selected because they are believed to be those that would respond to climate warming. Ice cover data were based on remote sensing data and were obtained from Wang et al. (2012).

\section{Nutrient input and concentration}

Nutrient input data consisted of estimates of annual phosphorus loading from the catchments (pload) and spring total phosphorus (TP) concentrations. Loading data were obtained from Dolan \& Chapra (2012, their tables 8 and 9). We chose to evaluate the influence of pload because there have been significant efforts to control/minimise phosphorus inputs to the lakes to mitigate eutrophication. The measure of nutrient concentration was April total phosphorus concentration (TP) obtained from U.S. E.P.A. Great Lakes National Program Office (GLNPO) Great Lakes Environmental Database (GLENDA, accessed 9 April 2013, https://cdx.epa.gov/). Samples were drawn from a number of depths from the surface to as deep as $130 \mathrm{~m}$. For a given year, we calculated the mean across all depths and sites because the lakes were not yet thermally stratified.

\section{Invasive mussel impact}

We used the numerical density of quagga mussels as an index of the filtering effect of dreissenid mussels overall, and hereafter, we will use the term 'invasive mussels'. Proportionally, zebra mussels were a minor component of invasive mussel density after the arrival of quagga mussels. Density data were obtained from four different sources. For Lake Michigan, data were taken from Nalepa, Fanslow \& Lang (2009, their Fig. 4) and were averaged (arithmetic mean) across four depth zones (16$30 \mathrm{~m}, 31-50 \mathrm{~m}, 51-90 \mathrm{~m}$ and $>90 \mathrm{~m}$ ) while, for Lake Huron, data were obtained from Nalepa et al. (2007) for 
the year 2000 and from French et al. (2009) for the years 2001-2007. For the year 2008 in Lake Huron, we used unpublished data (J. Schaeffer, United States Geological Survey Great Lakes Science Center). The data from Lake Michigan were from 40 locations covering approximately the southern third of the lake and not lakewide surveys. Based on maps in Nalepa et al. (2008), this limitation did not seem likely to bias the data. The data for Lake Huron in 2001-2008 were from 15 locations (French et al., 2009). Invasive mussel density data were not available from 1998 to 1999 in Lake Huron. As a result, these years were excluded from the analyses.

\section{Data analyses}

To determine whether temporal trends were present in chla and primary production at the annual scale, we analysed the annual means of these variables using a Mann-Kendall test modified to account for serial correlation (Yue \& Wang, 2004) using the R package USGSwsStats (Lorenz, 2013). We also used this test to evaluate the monthly data for the presence of trends within months among years. This test determines whether the slopes of the annual or monthly values (versus year) are significantly different from zero. Prior to analyses, chla $\left(\mu \mathrm{g} \mathrm{L}^{-1}\right)$ and primary production $\left(\mathrm{mg} \mathrm{C} \mathrm{m}^{2}\right.$ day $\left.^{-1}\right)$ values were logarithmically transformed (base 10). The data on chla concentration or mean rate of primary production were first fitted to global regression models with all potential explanatory variables included (without interactions). We modelled spring and annual chla and primary production separately because Fahnenstiel et al. (2010) suggested that benthic invasive mussels have access to epilimnetic waters only during unstratified portions of the year and therefore have less of an impact on annual estimates. The independent variables were standardised to have a mean of 0 and a standard deviation of 0.5 , so as to make their coefficients comparable (Grueber et al., 2011). We used an information-theoretic approach and the R package MuMIn (Barton, 2012) to fit and rank models (using relative likelihood) and to select the most supported models and/or most important explanatory variables from all the candidate models (Burnham \& Anderson, 2002). To evaluate the potential for uncertainty in interpretation and model parameter estimation that can arise from multicollinearity, we tested each regression model to ensure they had condition indices $<10$ (Belsley, 1991), using the colldiag function in the $\mathrm{R}$ package perturb (Hendrickx, 2012). This approach provided insight into the degree to which our explanatory variables covaried, which can make it difficult to separate the effects of one variable from those of another.

In addition to evaluating annual patterns in the magnitude of chla and primary production, we sought to determine whether there were seasonal/phenological changes and whether or not such changes were related to our climate variables. We used linear regression to determine whether there was any relationship between several climate indices and phenology indices. The phenology indices included the day of the year on which the pre-stratification chla peak occurred and the centre of gravity of seasonal chla for each year, which was the mean day of the year weighted by the chla values for each day. We evaluated monthly data (within months across years) using a Mann-Kendall test as described above for monthly chla data.

\section{Results}

Most of the factors chosen as explanatory variables for use in model selection varied during the study period (Fig. 2). Of these nine variables, two showed a significant trend in Lake Michigan, as determined using a Mann-Kendall test. Spring TP concentration declined significantly in both lakes ( $P=0.0002$ in both). Invasive mussel density increased in Lake Michigan $(P=0.005)$.

The seasonal pattern of chla changed between 2002 and 2003 (Lake Huron) or 2003 and 2004 (Lake Michigan). Before 2003 in Lake Huron, there were pre-stratification and autumn peaks in chla that either disappeared (spring; Fig. 3) or were greatly reduced (autumn). A similar pattern was observed in Lake Michigan, where the pre-stratification peak also disappeared (Fig. 4). In Lake Michigan, the autumn peak that had become apparent in 2004 was most pronounced in 2006-2008. In Lake Huron, there was a significant decrease over the years in chla in every month except July, August, September and November $(P<0.05$; Fig. 5$)$. In Lake Michigan, there were significant decreases in MarchSeptember $(P<0.05$; Fig. 5$)$. The seasonal pattern in chla (Fig. 6) was different from the seasonal pattern in primary production, with the latter showing the dominant influence of water temperature and light, with peaks in mid-summer. The seasonal patterns in primary production did not change much in either lake, but production declined overall (Fig. 7). Regression analyses of our phenology indices with date of stratification failed to identify significant models. The centre of gravity for chla concentrations was not significantly correlated with day of stratification $(P=0.41)$. Similarly, the day of peak 

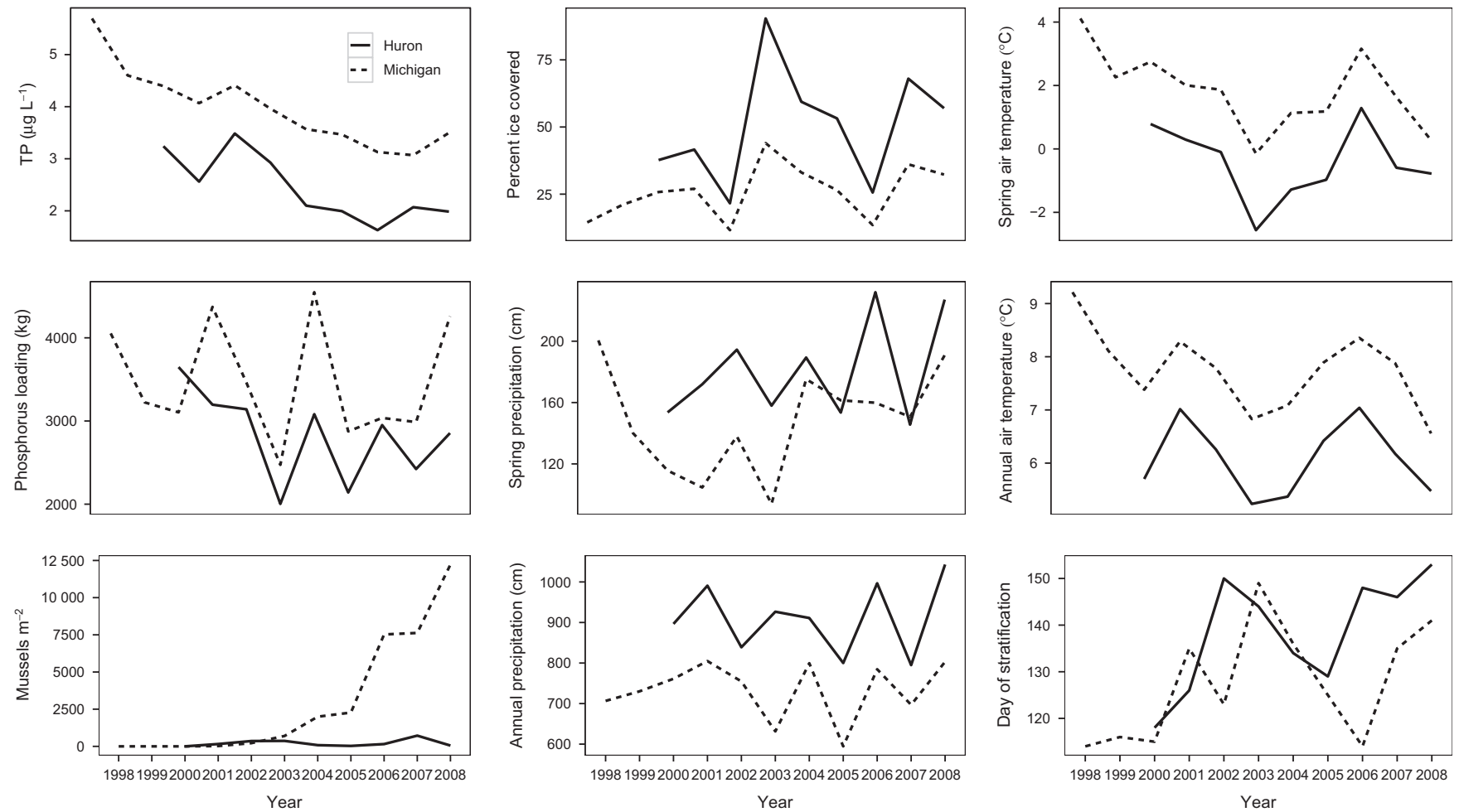

Fig. 2 Plot of explanatory variables included in fitting and selection of models for predicting chlorophyll a and primary production estimates in this study.

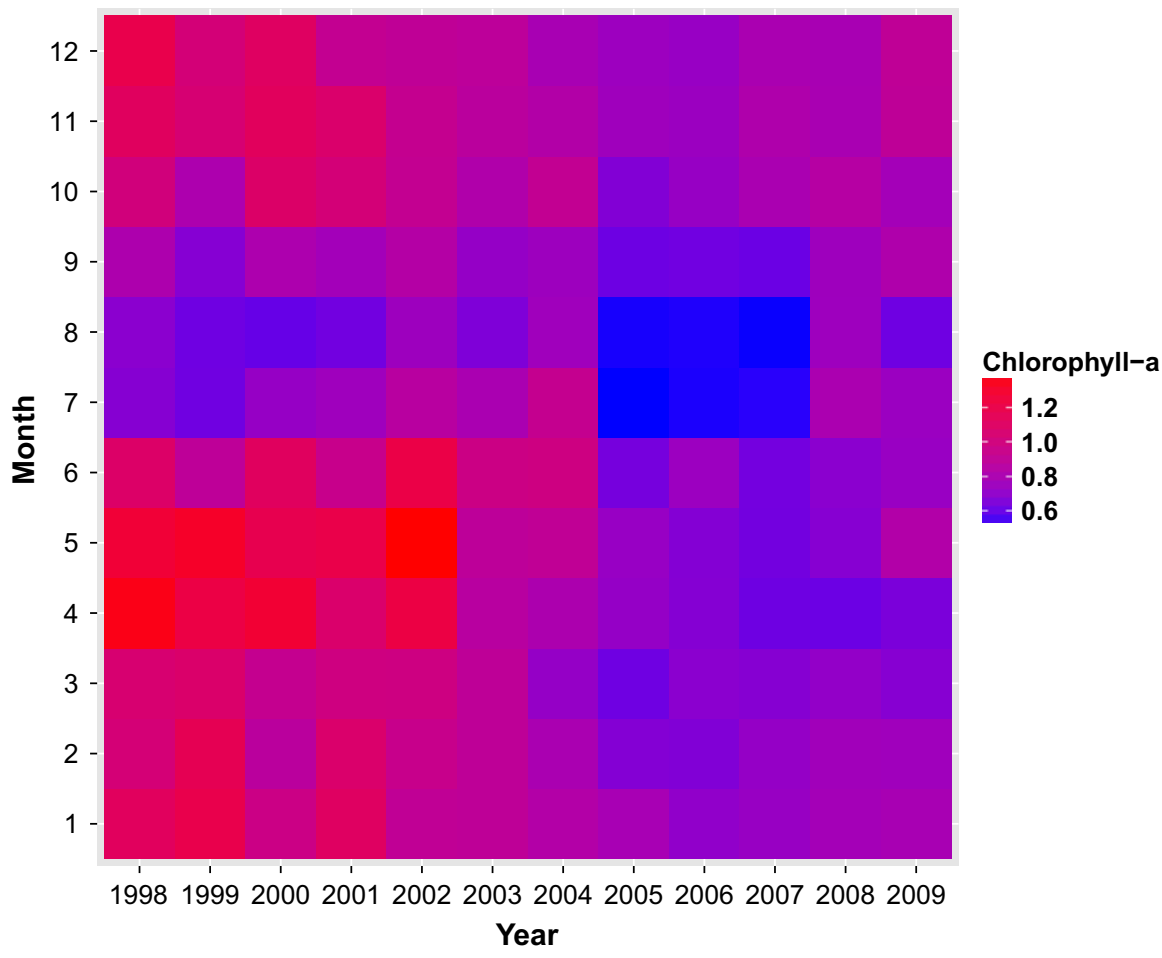

Fig. 3 Monthly mean chlorophyll a in Lake Huron in the years 1998-2009.

pre-stratification chla was not correlated with day of stratification $(P=0.68)$. Finally, there was no trend in either of these variables $(P>0.05)$.
A global model of factors influencing annual variation in mean spring chla was significant $\left(r^{2}=0.70\right.$; $P=0.001)$, and, based on the evaluation of diagnostic

(C) 2015 John Wiley \& Sons Ltd, Freshwater Biology, 60, 1029-1043 
Fig. 4 Monthly mean chlorophyll a in Lake Michigan in the years 1998-2009.

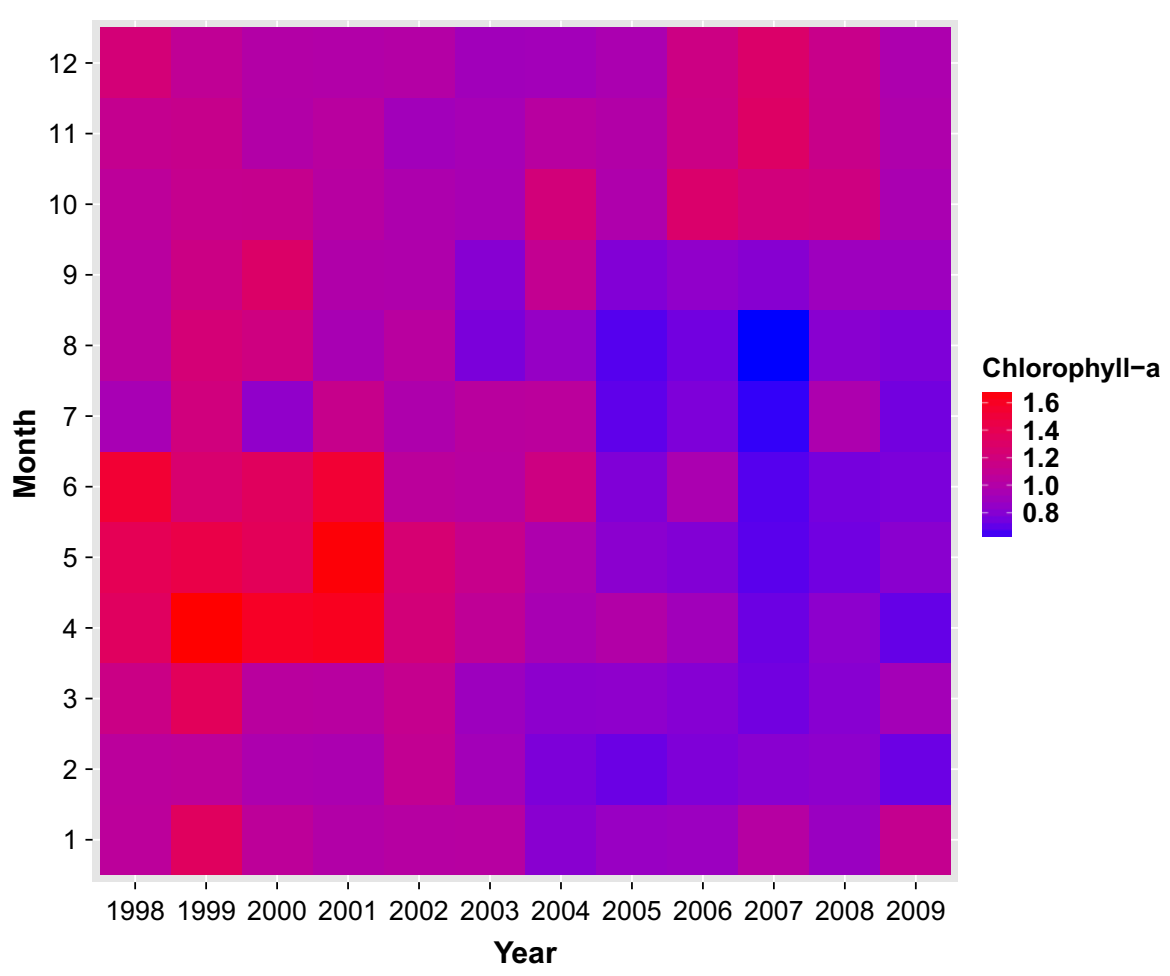

plots of residuals, the model fit was adequate. Condition indices were all $<10$, indicating there was little risk of multicollinearity. Relative likelihoods indicated that there was little support for a single best model. Therefore, we selected a set $(N=7)$ of models that included all those with relative likelihood $>0.135$ (Burnham \& Anderson, 2002) and used multi-model averaging and inference to estimate coefficients and relative importance (Table 1) of the explanatory variables. The variables TP and invasive mussel density were most important (relative importance 1.0 and 0.9 , respectively). The remaining variables had coefficients that were not significantly different from zero. Coefficients for TP and quagga mussel density were significantly different from zero, and their signs (positive for $\mathrm{TP}$, negative for quagga mussel density) were as expected. The standardised coefficient for TP (0.76) was much higher than the absolute value for quagga mussel coefficient $(-0.29)$, suggesting that TP was the more influential variable.

Analysis of annual mean chla also resulted in a significant global model $\left(r^{2}=0.88 ; P<0.0001\right)$ with adequate fit. Condition indices were all $<10$, indicating there was little risk of multicollinearity. From the global model, we identified five candidate models (Table 2) with some support (relative likelihood $>0.135$ ). As with spring chla, TP was identified as very influential (relative importance $=1.0$ ). Unlike results for spring chla, however, precipitation was also identified as important (relative importance $=1.0$ ); these two variables were the only ones with coefficients significantly different from zero. Both coefficients were positive, indicating that higher TP and higher precipitation were associated with higher annual mean chla. However, the standardised coefficient for TP (1.1) was much higher than that for precipitation (0.36), indicating that TP was more influential than precipitation. Other variables had little influence (values $<0.2$ ).

Spring primary production modelling resulted in a significant global model $\left(r^{2}=0.77 ; P=0.0003\right)$ with adequate fit. Condition indices were all $<10$, indicating there was little risk of multicollinearity. Model selection resulted in 19 models with relative likelihood $>0.135$ (Table 3). As with models described above, we used model averaging to identify the best model and influential variables. The variable TP was present in all models, had the highest relative importance (1.0) and was the only variable with a coefficient $(0.80)$ significantly different from zero.

Analyses to evaluate variation in estimates of annual mean primary production also resulted in a global model that was highly significant $\left(r^{2}=0.95 ; P \ll 0.001\right)$, and, based on the evaluation of diagnostic plots of residuals, fit was adequate. Condition indices were all $<10$, indicating there was little risk of multicollinearity. Five models had a relative likelihood $>0.135$ (Table 4). The variables TP, quagga mussel density and air temperature 


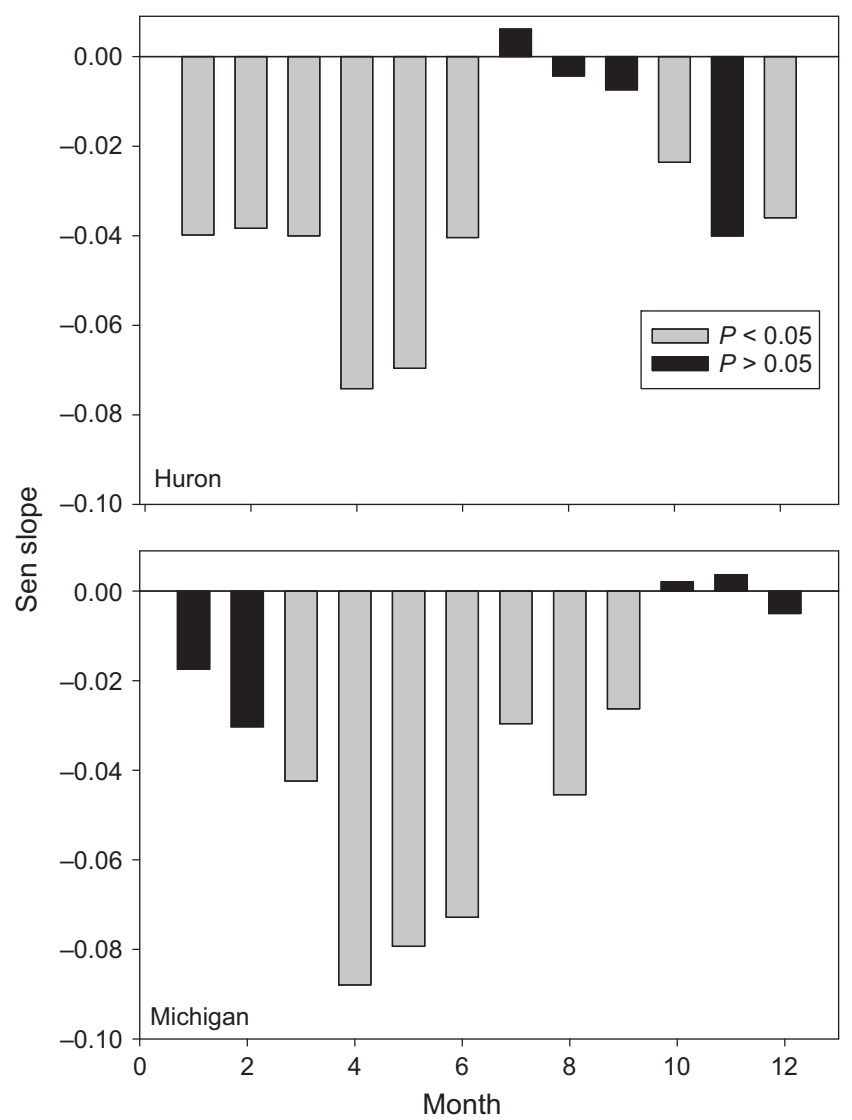

Fig. 5 Slope of the trend line for monthly mean chlorophyll a versus year for Lake Michigan and Lake Huron. Grey shading indicates slopes that were significantly different from zero $(P<0.05)$ while black shading indicates slopes that were not.

all had relative importance $=1.0$, and the coefficients for these three variables were significantly different from zero. The coefficient for TP was positive, which is consistent with expectation. Higher invasive mussel density was associated with lower primary production (i.e. the coefficient was negative). Finally, primary production was higher in warmer years. The magnitude of the coefficients for these variables indicated that TP (0.65) had the strongest influence, followed by air temperature (0.33) and quagga mussel density $(-0.17)$.

Primary production estimates for lakes Michigan and Huron differed in terms of total areal annual carbon fixation and total carbon fixed annually in the lake. Mean areal production in Lake Michigan during 1998-2008 was $192 \mathrm{~g} \mathrm{C} \mathrm{m}^{-2}$ year $^{-1} \quad(\mathrm{SE}=7.7)$, while the range during this period was $165-235 \mathrm{~g} \mathrm{C} \mathrm{m}^{-2}$ year $^{-1}$. In Lake Huron, the mean during 1998-2008 was $152 \mathrm{~g} \mathrm{C} \mathrm{m}^{-2}$ year $^{-1}$ (SE $=5.7$ ) and the range was 130 $184 \mathrm{~g} \mathrm{C} \mathrm{m}^{-2}$ year $^{-1}$. Estimated total annual production in Lake Michigan ranged from 9.5 to 13.6 tg C (assuming offshore values are representative of the other $7.5 \%$ of the lake we called nearshore). Estimated total annual production in Lake Huron ranged from 7.7 to 11.0 tg C (assuming the offshore value can be extrapolated to the remaining $20 \%$ of the lake we called nearshore). This was $19-20 \%$ less than in Lake Michigan even though Lake Huron is larger.

\section{Discussion}

Chla and primary production both declined at the whole lake spatial scale and at various temporal scales during the years 1998-2008. Seasonal patterns in chla changed in both lakes, but changes were not identical. The data used in our analyses provided relatively strong support for our hypothesis that chla and primary production were influenced by nutrients, climate and invasive mussels. However, our hypothesis that ice cover directly negatively influenced chla and primary production was not supported by the data.

Long-term seasonal patterns in chla and primary production were generally consistent with other recent reports. The pre-stratification peak in chla has disappeared, as found previously by Fahnenstiel et al. (2010), Kerfoot et al. (2010) and Barbiero et al. (2012). Pre-stratification primary production has also declined, which is consistent with the findings of Fahnenstiel et al. (2010) for Lake Michigan. However, unlike Fahnenstiel et al. (2010) and Pothoven \& Fahnenstiel (2013), we found a decline in primary production throughout the summer (not just in June) in Lake Michigan.

Although the direction of trends in chla and primary production agrees with other studies, the magnitude of the changes observed was less than has been reported previously. For example, Fahnenstiel et al. (2010) observed a $75 \%$ decline in spring chla from the mid1990s to 2007-2008 at two stations in Lake Michigan, while Barbiero, Lesht \& Warren (2011), also using satellite data, found a decline in spring chla of $50-60 \%$ in 2003-2006 relative to 1998-2002. The declines observed in spring chla were $27 \%$ for Lake Michigan and 35\% in Lake Huron. We observed 21 and $28 \%$ decreases in March-November chla in lakes Michigan and Huron, respectively. We found somewhat larger (30 and 40\%, respectively) decreases in annual primary production than for chla. We also observed smaller decreases in spring (25\%) and annual (30\%) primary production in Lake Michigan than reported by Fahnenstiel et al. (2010), who found a 70\% decrease from the mid-1990s to 20072008 at two stations in Lake Michigan.

It is not clear why the decreases we observed in spring chla and primary production were smaller than

(C) 2015 John Wiley \& Sons Ltd, Freshwater Biology, 60, 1029-1043 


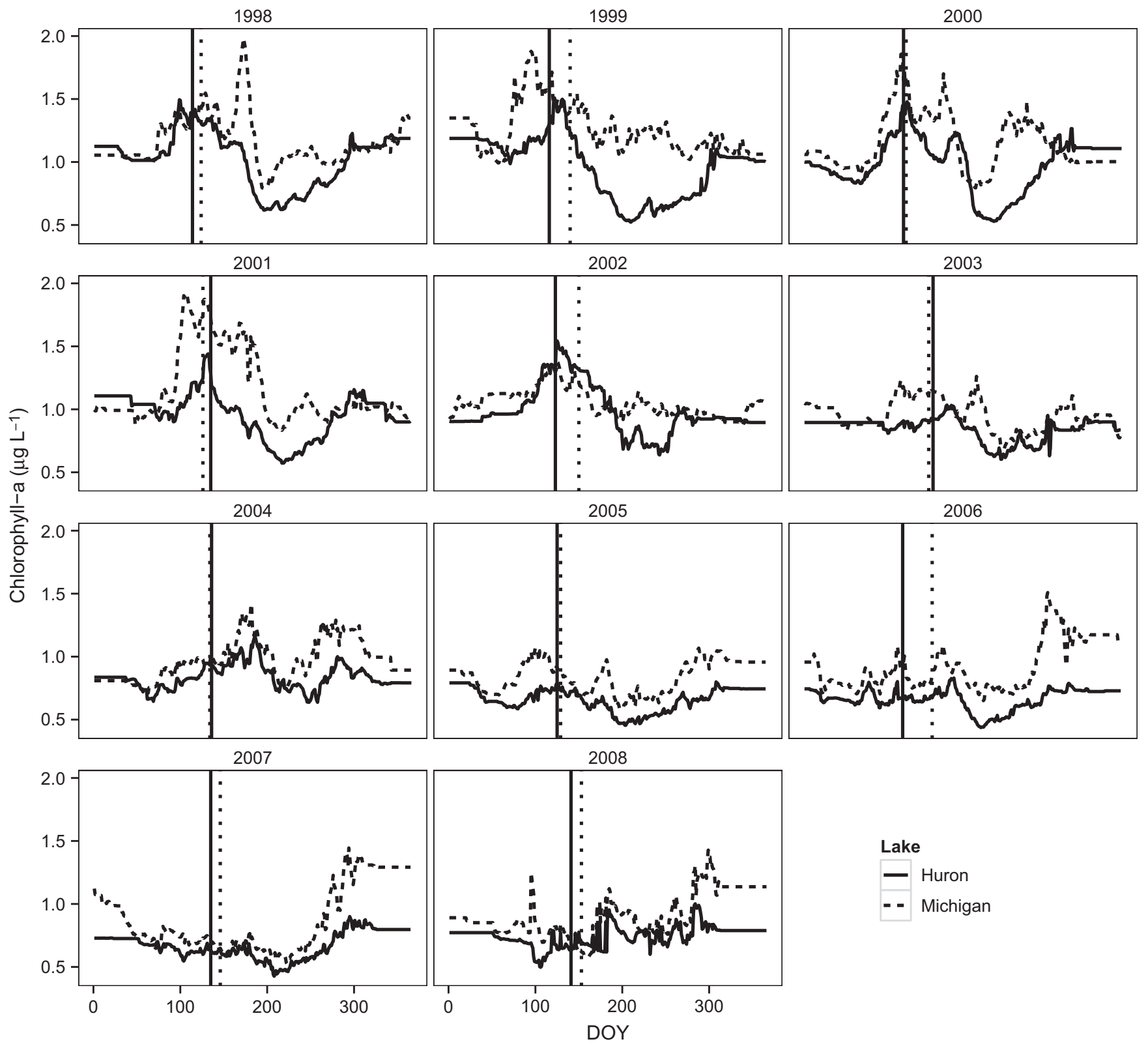

Fig. 6 Chlorophyll a versus day of year in lakes Michigan and Huron during the years 1998-2008. Vertical lines denote the day of year on which thermal stratification occurred.

reported previously. One possibility is that our estimates included areas of high chla and/or primary production, such as Green Bay, Saginaw Bay and North Channel (not included in previous studies comparing recent estimates with those in the 1990s and 2000s). Our results were derived from all parts of the lakes deeper than $30 \mathrm{~m}$, while those from Barbiero et al. $(2011,2012)$ and Fahnenstiel et al. (2010) were from a more limited area. However, the magnitude of changes in annual chla from our data, recalculated after excluding Green Bay, Saginaw Bay and the North Channel, changed by $<2 \%$, suggesting that inclusion of the high-chlorophyll areas was not the cause of differences. Regardless of differences in the magnitude of the changes we report and those of other recent studies, the evidence overall clearly indicates that both chla and PP have decreased in both lakes. Further, using satellite data, we were able to achieve much finer spatiotemporal resolution than possible using conventional sampling approaches.

As shown earlier, our mean daily estimates of primary production for Lake Michigan were similar to those of Fahnenstiel et al. (2010). However, they were also in the 


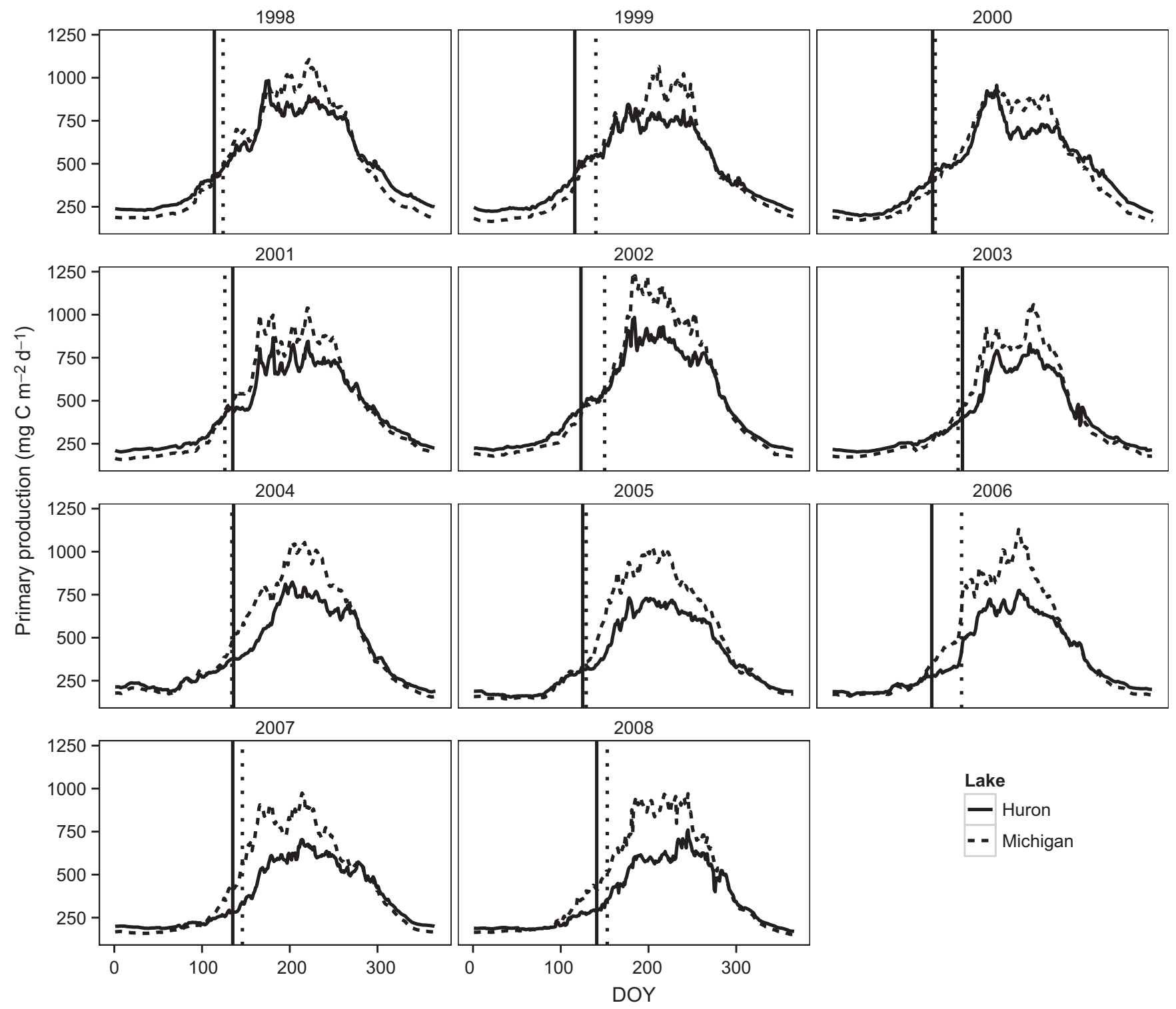

Fig. 7 Primary production versus day of year in lakes Michigan and Huron during the years 1998-2008. Vertical lines denote the day of year on which thermal stratification occurred.

same range as reported by Vollenweider et al. (1974). Our annual areal estimates ranged from 165 to $235 \mathrm{~g} \mathrm{C} \mathrm{m}^{-2}$ (mean $192 \mathrm{~g} \mathrm{C} \mathrm{m}^{-2}$ ), quite similar to the mean of values from five different stations $\left(167 \mathrm{~g} \mathrm{C} \mathrm{m}^{-2}\right.$ ) estimated by Fee (1973). There are no primary production data from Lake Huron in the 1990s with which to compare our estimates, but earlier annual areal estimates from the 1970s ranged from 76 to $92 \mathrm{~g} \mathrm{C} \mathrm{m}^{-2}$, depending on the area of the lake (Vollenweider et al., 1974; Watson, Culp \& Nicholson, 1976). These values are lower than the range of annual areal values we estimated (130-184 $\mathrm{g} \mathrm{C} \mathrm{m}^{-2}$ ). In the case of both lakes, our estimates are much higher than predictions from equations based on either latitude or mean annual water temperature and previously published primary production (Alin \& Johnson, 2007). The latitudebased equation predicts 73 and $69 \mathrm{~g} \mathrm{C} \mathrm{m}^{-2}$ year $^{-1}$ for lakes Michigan and Huron, respectively, while the Alin \& Johnson (2007) equation, based on water temperature, predicts 56 and $61 \mathrm{~g} \mathrm{C} \mathrm{m}^{-2}$ year $^{-1}$. Although Barbiero et al. (2012) reported a convergence of trophic status in the three upper Laurentian Great Lakes, our results indicate that, in 2008, total annual primary production in lakes Michigan and Huron was 9.5 and 7.7 tg year $^{-1}$, respectively, both higher than the 7.6 tg year $^{-1}$ produced in Lake Superior (Sterner, 2010). The estimate we cite for Lake Superior does not include the adjustment that Sterner (2010) made to account for primary

(C) 2015 John Wiley \& Sons Ltd, Freshwater Biology, 60, 1029-1043 
Table 1 Confidence set of models showing explanatory variables most supported by the data in analyses of mean pre-stratification chlorophyll a in lakes Michigan and Huron. The global model is shown in the final row

\begin{tabular}{lllll}
\hline Explanatory variables & $A I C_{\mathrm{c}}$ & $\Delta A I C_{\mathrm{c}}$ & Weight & $\begin{array}{l}\text { Relative } \\
\text { likelihood }\end{array}$ \\
\hline TP, quagga & -60.5 & 0 & 0.48 & 1.00 \\
TP, quagga, sprecip & -57.8 & 2.7 & 0.124 & 0.26 \\
TP, quagga, strat & -57 & 3.51 & 0.083 & 0.17 \\
TP, quagga, ice & -57 & 3.55 & 0.082 & 0.17 \\
TP, quagga, atemp & -57 & 3.56 & 0.081 & 0.17 \\
TP, quagga, & -57 & 3.59 & 0.080 & 0.17 \\
$\quad$ sprecip, pload & & & & \\
TP & -56.7 & 3.85 & 0.070 & 0.15 \\
TP, pload, quagga, & -37.2 & 23.30 & 0.00 & 0.00 \\
sprecipitation, & & & & \\
satemp, ice, strat & & & & \\
\hline
\end{tabular}

$\mathrm{TP}$, April total phosphorus concentration; quagga, numerical density of quagga mussels; sprecip, spring precipitation; ice, per cent ice cover; satemp, spring air temperature in the lake basin; pload, annual external phosphorus loading; strat, day of year on which thermal stratification occurred.

Table 2 Explanatory variables in the confidence set of models tested to explain variation in mean March-November chlorophyll a in lakes Michigan and Huron. The confidence set consisted of models with relative likelihood $>0.135$. The global model is shown in the final row

\begin{tabular}{lccll}
\hline Explanatory variables & AIC & \multicolumn{1}{c}{$\Delta \mathrm{AIC}_{\mathrm{c}}$} & Weight & $\begin{array}{l}\text { Relative } \\
\text { likelihood }\end{array}$ \\
\hline TP, precip & -79.4 & 0 & 0.42 & 1 \\
TP, precip, strat & -77.9 & 1.41 & 0.21 & 0.472367 \\
TP, precip, atemp & -77.1 & 2.23 & 0.14 & 0.316637 \\
TP, precip, quagga & -77.1 & 2.26 & 0.14 & 0.316637 \\
TP, pload, precip & -76.5 & 2.83 & 0.10 & 0.23457 \\
TP, pload, precip, & -64.9 & 14.46 & 0.00 & 0 \\
quagga, atemp, strat & & & & \\
\hline
\end{tabular}

TP, April total phosphorus concentration; precip, annual precipitation in lake basin; quagga, numerical density of quagga mussels; pload, annual external phosphorus loading; strat, day of year on which thermal stratification occurred; atemp, mean annual air temperature in lake basin; pload, phosphorus loading from catchment.

production that was channelled into the pool of dissolved organic carbon. This adjustment resulted in an annual estimate for Lake Superior of $9.7 \mathrm{tg}$ (Sterner, 2010). After accounting for the carbon incorporated into both particulate and dissolved pools, carbon fixation in Lake Superior in recent years was 1.02 and 1.3 times that in lakes Michigan and Huron, respectively, even though the area of Lake Superior is 1.4 and 1.38 times that of lakes Michigan and Huron, respectively. Without accounting for this dissolved pool, both Michigan and Huron had higher production than Lake Superior. Thus, it would seem that, even though total annual carbon fixation in
Table 3 Explanatory variables in the confidence set of models tested to explain variation in pre-stratification primary production in lakes Michigan and Huron. The confidence set consisted of models with relative likelihood $>0.135(N=19)$, but only the top four (relative likelihood $>0.5$ ) are shown. The global model is shown in the final row

\begin{tabular}{lccll}
\hline Explanatory variables & $A I C_{\mathrm{c}}$ & $\Delta A I C_{\mathrm{c}}$ & Weight & $\begin{array}{l}\text { Relative } \\
\text { likelihood }\end{array}$ \\
\hline TP, sprecip & -68.1 & 0 & 0.137 & 1 \\
TP, sprecip, quagga & -67.8 & 0.3 & 0.118 & 0.86 \\
TP, quagga & -67.6 & 0.47 & 0.109 & 0.78 \\
TP & -67.3 & 0.78 & 0.093 & 0.68 \\
TP, pload, quagga, & -51.8 & 16.26 & 0.00 & 0.00 \\
$\quad$ sprecip, satemp, strat, ice & & & &
\end{tabular}

$\mathrm{TP}$, April total phosphorus concentration; sprecip, spring precipitation in the lake basin; quagga, numerical density of quagga mussels; pload, annual external phosphorus loading; satemp, spring air temperature in the basin; strat, day of year on which thermal stratification occurred; ice, maximum per cent ice cover.

the lakes is relatively similar, lakes Michigan and Huron may still be more productive than Lake Superior.

Our results support the hypothesis that trends in spring and March-November chla and primary production are the result of several factors rather than invasive mussels alone. Although mussel density was associated with spring chla and annual primary production, it was less influential than TP concentrations (for spring chla and annual primary production) or air temperature (for annual primary production). Further, invasive mussel density was not identified as contributing to temporal trends in annual mean chla and primary production in spring. Rather, TP (for both annual chla and primary production) and precipitation (for annual chla) were the key influences on these variables. These findings suggest that previous conclusions (Fahnenstiel et al., 2010) that quagga mussels were the sole cause of observed trends in chla and primary production in these two lakes may have been oversimplifications.

Our finding that TP influenced chla and primary production is consistent with the conventional paradigm (Dillon \& Rigler, 1974). A number of recent studies have noted a decrease in TP in lakes Michigan and Huron (Barbiero et al., 2011; Chapra \& Dolan, 2012), which should result in decreased chla and primary production. The cause of this reduction in TP has been attributed to filtering by invasive mussels, as well to decreased catchment loading (Chapra \& Dolan, 2012). Chapra \& Dolan (2012) argued that the decrease in TP after 1990 was greater than could be explained by decreased loading and attributed this to filtering by invasive mussels. Pothoven \& Fahnenstiel (2013) suggested that the decline in early summer chla in Lake Michigan was the 
Table 4 Explanatory variables in the confidence set of models tested to explain variation in mean daily primary production (March-November) in lakes Michigan and Huron. The confidence set consisted of models with relative likelihood $>0.135$. The global model is shown in the final row

\begin{tabular}{|c|c|c|c|c|}
\hline Explanatory variables & $A I C_{\mathrm{c}}$ & $\Delta A I C_{c}$ & Weight & $\begin{array}{l}\text { Relative } \\
\text { likelihood }\end{array}$ \\
\hline $\mathrm{TP}$, quagga, atemp & -91.6 & 0 & 0.46 & 1 \\
\hline $\mathrm{TP}$, quagga, pload, atemp & -90 & 1.57 & 0.21 & 0.449329 \\
\hline TP, quagga, atemp, strat & -89.7 & 1.85 & 0.183 & 0.386741 \\
\hline $\begin{array}{l}\mathrm{TP} \text {, quagga, atemp, } \\
\text { pload, strat }\end{array}$ & -88 & 3.62 & 0.075 & 0.165299 \\
\hline $\begin{array}{l}\text { TP, quagga, atemp, } \\
\text { pload, precip, strat }\end{array}$ & -82.2 & 9.4 & 0.00 & 0.00 \\
\hline
\end{tabular}

TP, April total phosphorus concentration; quagga, numerical density of quagga mussels; pload, annual external phosphorus loading; precip, annual precipitation (lake basin + over-lake); atemp, mean air temperature; strat, day of year on which thermal stratification occurred.

result of filtering by mussels in spring, but they also suggested that changes in nutrient cycling could not be ruled out.

The role of invasive mussels in nutrient cycling in lakes is poorly understood. Bootsma \& Liao (2013) suggested that dreissenids are likely to have a number of effects. By filtering phytoplankton, they remove algaeborne nutrients from the water. By filtering resuspended sediment that contains $\mathrm{P}$ that the phytoplankton might use, they may also reduce P availability directly. Eadie et al. (2002) found that sediment resuspension was a very important source of nutrients. However, Brooks \& Edgington (1994) argued that most P from lake sediments was released in spring, not as a result of sediment resuspension but rather because phytoplankton demand for $\mathrm{P}$ during the spring bloom disrupted an apatite equilibrium between sediment and water, causing $\mathrm{P}$ to be released from the sediments under oxic, non-turbulent conditions. This is in contrast to the usual view that $\mathrm{P}$ is released mainly under anoxic conditions (Hupfer \& Lewandowski, 2008). Bootsma \& Liao (2013) argued that invasive mussels, by reducing spring phytoplankton biomass, may be preventing this disequilibrium and associated $\mathrm{P}$ release. Because invasive mussels have access to the whole water column during periods of mixing, they could filter the algae and/or resuspended nutrients and prevent their use elsewhere, as well as reduce the algal demand for P. In an effort to identify factors that influenced TP concentrations used in this study, we used the regression and information-theoretic methods described above to evaluate models with TP as the response variables and P loading, invasive mussel density, ice cover and spring precipitation as explanatory variables. We found that the global model, while significant $\left(r^{2}=0.55\right.$; $P=0.002)$, explained less variation in TP than might be expected. Because of the similarity in relative likelihoods, we used model averaging, which resulted in only ice cover and spring precipitation having coefficients that were different from zero (0.45 and 0.47 , respectively). Our data do not support the contention that TP concentration in spring is a function of invasive mussel density but is instead influenced by ice cover, as suggested by previous studies (Rodgers \& Salisbury, 1981; Nichols, 1998). Further, our data indicate spring precipitation has a positive influence on spring TP. Given these results, we conclude that existing data do not support the contention that invasive mussels have independently reduced spring TP and suggest that the role of invasive mussels in nutrient cycling remains poorly understood.

Our identification of invasive mussel density as one negative influence on spring chla and annual primary production is consistent with conclusions by other researchers (Cha, Stow \& Bernhardt, 2013). In support of the view that changes have been the result of invasive mussels, other studies have relied primarily upon (a) the long-term temporal coherence of decreases in chla/primary production and mussel abundance, (b) restriction of decreases in chla and primary production to portions of the year when mussels have access to the entire water column, (c) the magnitude of theoretical estimates of mussel grazing capacity or (d) all three. Our results suggest that, even though invasive mussels do not have access to the entire water column once the lakes are stratified, they have had a negative impact on annual mean PP and spring chla. Unlike other studies, however, we found that TP and climate are more important than invasive mussels.

In support of our hypothesis that there were climatic influences on chla and primary production, we identified two climate-related variables (annual air temperature and annual precipitation) as important predictors. There was apparently no linkage between stratification date and seasonal patterns in chla or primary production, which suggests that any influence of climate on phenology has not led to a change in either. Further, unlike typical climate warming scenarios where stratification date occurs earlier (Shimoda et al., 2011), during our study period, stratification was delayed in later years. Both air temperature and precipitation were positively associated with chla and primary production in our study, although the mechanisms are not clear. One possibility is that higher air temperature reduces ice cover, which facilitates wind-induced mixing and nutrient resuspension (Nichols, 1998; Schwab et al., 2006). 
However, air temperature was not an important predictor of TP concentration in our data. Rather, ice cover and spring precipitation were the most important influences on TP, indicating an indirect influence of air temperature, at best. Depending on when it falls in the basin, precipitation may also influence chla and primary production. Increases in the form of rain would cause increased run-off, which could bring more nutrients to the lakes from non-monitored or diffuse non-point sources. Our hypothesis that ice cover negatively influenced chla and primary production was not supported by the data, but, like Nichols (1998), we did observe a relationship between ice cover and spring TP. Our results indicate that further research will be required to understand more completely the diffuse mechanisms by which climate influences chla and primary production.

We present evidence that factors other than invasive mussels have played an important role in the decrease in chla and primary production observed in lakes Michigan and Huron. This evidence, along with findings of Rowe et al. (2015), indicates that the interplay between nutrients, climate and invasive mussels has been, and will continue to be, complicated and difficult to predict. While some of our findings are far from conclusive, it is apparent that TP concentration has been at least as important as the effect of invasive mussels and that TP has varied independent of invasive mussels. While none of the 'traditional links' between climate and phytoplankton phenology appeared to apply, climate was still important. Future work should focus on identifying the mechanisms by which temperature and precipitation influence chla and primary production, and factors regulating TP.

\section{Acknowledgments}

We thank Bo Bunnell for intellectually supporting this line of research and pursuing the funding that made it possible. Funding for this work was provided by the U.S. Geological Survey, National Climate Change and Wildlife Science Center. Any use of trade, product, or firm names is for descriptive purposes only and does not imply endorsement by the U.S. Government. This article is Contribution 1922 of the U.S. Geological Survey Great Lakes Science Center.

\section{References}

Alin S.R. \& Johnson T.C. (2007) Carbon cycling in large lakes of the world: a synthesis of production, burial, and lake-atmosphere exchange estimates. Global Biogeochemical Cycles, 21, 1-12.
Baith K.R., Lindsay R., Fu F. \& McClain C. (2001) SeaDAS, a data analysis system for ocean-color satellite sensors. EOS, Transactions American Geophysical Union, 82, 202.

Barbiero R.P., Lesht B.M. \& Warren G.J. (2011) Evidence for bottom-up control of recent shifts in the pelagic food web of Lake Huron. Journal of Great Lakes Research, 37, 78-85.

Barbiero R.P., Lesht B.M. \& Warren G.J. (2012) Convergence of trophic state and the lower food webs of lakes Huron, Michigan, and Superior. Journal of Great Lakes Research, 38, 368-380.

Barton K. (2012). MuMIn: Multi-Model Inference. R Package Version 1.8.0. http://CRAN.R-project.org/package $=\mathrm{Mu}-$ MIn.

Beeton A.M. (1965) Eutrophication of the St. Lawrence Great Lakes. Limnology and Oceanography, 10, 240254.

Behrenfeld M.J. \& Falkowski P.G. (1997a) A consumer's guide to phytoplankton primary productivity models. Limnology and Oceanography, 42, 1479-1491.

Behrenfeld M.J. \& Falkowski P.G. (1997b) Photosynthetic rates derived from satellite-based chlorophyll concentration. Limnology and Oceanography, 42, 1-20.

Belsley D.A. (1991) A guide to using the collinearity diagnostics. Computer Science in Economics and Management, 4, 33-50.

Bootsma H. \& Liao Q. (2013) Nutrient cycling by dreissenid mussels: controlling factors and ecosystem response. In: Quagga and Zebra Mussels: Biology, Impacts, and Control, 2nd edn. (Eds T.F. Nalepa \& D.W. Schloesser), pp. 555574. CRC Press, Boca Raton.

Brooks A.S. \& Edgington D.N. (1994) Biogeochemical control of phosphorus cycling and primary production in Lake Michigan. Limnology and Oceanography, 39, 961968.

Burnham K.P. \& Anderson D.R. (2002) Model selection and multimodel inference: a practical information-theoretic approach, 2nd edn. Springer, New York, p. 488.

Cha Y., Stow C.A. \& Bernhardt E.S. (2013) Impacts of dreissenid mussel invasions on chlorophyll and total phosphorus in 25 lakes in the USA. Freshwater Biology, 58, 192-206.

Chapra S.C. \& Dolan D.M. (2012) Great Lakes total phosphorus revisited: 2. Mass balance modeling. Journal of Great Lakes Research, 38, 741-754.

Colby P.J., Spangler G.R., Hurley D.A. \& McCombie A.M. (1972) Effects of eutrophication on salmonid communities in oligotrophic lakes. Journal of the Fisheries Research Board of Canada, 29, 975-983.

Croley T.E. II. (1995) Laurentian Great Lakes dynamics, climate, and response to change. In: The role of water and the hydrological cycle in global change. Global environmental change, volume 31 (Eds. H.R. Oliver \& S.A. Oliver), pp 253-296. Springer-Verlag, NATO Advanced Science Institutes Series 1, Berlin. 
Dean W.E. \& Gorham E. (1998) Magnitude and significance of carbon burial in lakes, reservoirs, and peatlands. Geology, 26, 535-538.

Dillon P.J. \& Rigler F.H. (1974) The phosphorus-chlorophyll relationship in lakes. Limnology and Oceanography, 19, 767-773.

Dolan D.M. \& Chapra S.C. (2012) Great Lakes total phosphorus revisited: 1. Loading analysis and update (19942008). Journal of Great Lakes Research, 38, 730-740.

Eadie B.J., Schwab D.J., Johengen T.H., Lavrentyev P.J., Miller G.S., Holland R.E. et al. (2002) Particle transport, nutrient cycling, and algal community structure associated with a major winter-spring sediment resuspension event in Southern Lake Michigan. Journal of Great Lakes Research, 28, 324-337.

Eppley R.W. (1972) Temperature and phytoplankton growth in the sea. Fishery Bulletin, 70, 1068-1085.

Evans M.A., Fahnenstiel G. \& Scavia D. (2011) Incidental oligotrophication of North American Great Lakes. Environmental Science and Technology, 45, 3297-3303.

Fahnenstiel G., Pothoven S., Vanderploeg H., Klarer D., Nalepa T. \& Scavia D. (2010) Recent changes in primary production and phytoplankton in the offshore region of southeastern Lake Michigan. Journal of Great Lakes Research, 38, 582-583.

Fee E.J. (1969) A numerical model for the estimation of integral photosynthetic production, integrated over time and depth in natural waters. Limnology and Oceanography, 14, 906-911.

Fee E.J. (1973) A numerical model for determining integral primary production and its application to Lake Michigan. Journal of the Fisheries Research Board of Canada, 30, 14471468.

French J.R.P., Schaeffer J.S., Roseman E.F., Kiley C.S. \& Fouilleroux A. (2009) Abundance and distribution of benthic macroinvertebrates in offshore soft sediments in Western Lake Huron, 2001-2007. Journal of Great Lakes Research, 35, 120-127.

Great Lakes Water Quality Agreement (GLWQA) (1978) Revised Great Lakes Water Quality Agreement of 1978. International Joint Commission, Windsor, Ontario.

Grueber C.E., Nakagawa S., Laws R.J. \& Jamieson I.G. (2011) Multimodel inference in ecology and evolution: challenges and solutions. Journal of Evolutionary Biology, 24, 699-711.

Hendrickx J. (2012). perturb: Tools for Evaluating Collinearity. $R$ Package Version 2.05. http://CRAN.R-project.org/package $=$ perturb.

Hupfer M. \& Lewandowski J. (2008) Oxygen controls the phosphorus release from lake sediments - a long-lasting paradigm in limnology. International Review of Hydrobiology, 93, 415-432.

Kerfoot W.C., Yousef F., Green S.A., Budd J.W., Schwab D.J. \& Vanderploeg H.A. (2010) Approaching storm: dis- appearing winter bloom in Lake Michigan. Journal of Great Lakes Research, 36, 30-41.

Lesht B.M., Barbiero R.P. \& Warren G.J. (2013) A band-ratio algorithm for retrieving open-lake chlorophyll values from satellite observations of the Great Lakes. Journal of Great Lakes Research, 39, 138-152.

Lesht B.M., Stroud J.R., McCormick M.J., Fahnenstiel G.L., Stein M.L., Welty L.J. et al. (2002) An event-driven phytoplankton bloom in southern Lake Michigan observed by satellite. Geophysical Research Letters, 29, 67-61-67-64.

Lorenz D.L. (2013) USGSwsStats-An R Package for the Analysis of Hydrologic Data Version 0.6. https://github.com/ USGS-R/usgs-r.github.com/tree/master/src/contrib.

Madenjian C.P., Rutherford E.S., Blouin M.A., Sederberg B.J. \& Elliott J.R. (2011) Spawning habitat unsuitability: an impediment to cisco rehabilitation in Lake Michigan? North American Journal of Fisheries Management, 31, 905913.

Morel A., Huot Y., Gentili B., Werdell P.J., Hooker S.B. \& Franz B.A. (2007) Examining the consistency of products derived from various ocean color sensors in open ocean (Case 1) waters in the perspective of a multi-sensor approach. Remote Sensing of Environment, 111, 69-88.

Morel A. \& Prieur L. (1977) Analysis of variations in ocean color. Limnology and Oceanography, 22, 709-722.

Nalepa T.F., Fanslow D.L. \& Lang G.A. (2009) Transformation of the offshore benthic community in Lake Michigan: recent shift from the native amphipod Diporeia spp. to the invasive mussel Dreissena rostriformis bugensis. Freshwater Biology, 54, 466-479.

Nalepa T.F., Fanslow D.L., Lang G.A., Lamarand D.B., Cummins L. G. \& Carter G. S. (2008). Abundances of the Amphipod Diporeia spp. and the Mussels Dreissena polymorpha and Dreissena rostriformis bugensis in Lake Michigan 1994-1995, 2000, and 2005. NOAA Technical Memorandum GLERL-144.

Nalepa T.F., Fanslow D.L., Pothoven S.A., Foley A.J. \& Lang G.A. (2007) Long-term trends in benthic macroinvertebrate populations in Lake Huron over the past four decades. Journal of Great Lakes Research, 33, 421-436.

Nichols K.H. (1998) El Niño, ice cover, and Great Lakes phosphorus: implications for climate warming. Limnology Oceanography, 43, 715-719.

O'Reilly C.M., Alin S.R., Plisnier P.D., Cohen A.S. \& McKee B.A. (2003) Climate change decreases aquatic ecosystem productivity of Lake Tanganyika, Africa. Nature, 424, 766-768.

Pothoven S.A. \& Fahnenstiel G.L. (2013) Recent change in summer chlorophyll a dynamics of southeastern Lake Michigan. Journal of Great Lakes Research, 39, 287-294.

Quinn F.H. \& Kelley R.N. (1983). Great Lakes Monthly Hydrologic Data. NOAA Data Report ERL GLERL-26. pp 79.

Riley S.C., Roseman E.F., Nichols S.J., O'Brien T.P., Kiley C.S. \& Schaeffer J.S. (2008) Deepwater demersal fish 
community collapse in Lake Huron. Transactions of the American Fisheries Society, 137, 1879-1890.

Rodgers P. \& Salisbury D. (1981) Water quality modeling of Lake Michigan and consideration of the anomalous ice cover of 1976-1977. Journal of Great Lakes Research, 7, 467480.

Rowe M.D., Anderson E.J., Wang J. \& Vanderploeg H.A. (2015) Modeling the effect of invasive quagga mussels on the spring phytoplankton bloom in Lake Michigan. Journal of Great Lakes Research. doi: http://dx.doi.org/ 10.1016/j.jglr.2014.12.018, in press.

Scavia D., Fahnenstiel G.L., Evans M.S., Jude D.J. \& Lehman J.T. (1986) Influence of salmonine predation and weather on long-term water quality trends in Lake Michigan. Canadian Journal of Fisheries and Aquatic Sciences, 43, 435443.

Schwab D.J., Eadie B.J., Assel R.A. \& Roebber P.J. (2006) Climatology of large sediment resuspension events in southern lake Michigan. Journal of Great Lakes Research, 32, $50-62$.

Schwab D.J., Leshkevich G.A. \& Muhr G.C. (1999) Automated mapping of surface water temperature in the Great Lakes. Journal of Great Lakes Research, 25, 468-481.

Shimoda Y., Azim M.E., Perhar G., Ramin M., Kenney M.A., Sadraddini S. et al. (2011) Our current understanding of lake ecosystem response to climate change: what have we really learned from the north temperate deep lakes? Journal of Great Lakes Research, 37, 173-193.
Shuchman R.A., Sayers M., Fahnenstiel G.L. \& Leshkevich G. (2013) A model for determining satellite-derived primary productivity estimates for Lake Michigan. Journal of Great Lakes Research, 39, 46-54.

Sterner R.W. (2010) In situ-measured primary production in Lake Superior. Journal of Great Lakes Research, 36, 139-149.

Vanderploeg H.A., Liebig J.R., Nalepa T.F., Fahnenstiel G.L. \& Pothoven S.A. (2010) Dreissena and the disappearance of the spring phytoplankton bloom in Lake Michigan. Journal of Great Lakes Research, 36, 50-59.

Vollenweider R.A., Munawar M. \& Stadelman P. (1974) A comparative review of phytoplankton and primary production in the Laurentian Great Lakes. Journal of the Fisheries Research Board of Canada, 31, 739-762.

Wang J., Bai X., Hu H., Clites A., Colton M. \& Lofgren B. (2012) Temporal and spatial variability of Great Lakes ice cover, 1973-2010. Journal of Climate, 25, 1318-1329.

Watson N.H.F., Culp L.R. \& Nicholson H.F. (1976) Chlorophyll $a$ and primary production in Georgian Bay, North Channel, and Lake Huron April to December 1974. Canadian Fisheries and Marine Service Technical Report No. 600.

Yue S. \& Wang C.Y. (2004) The Mann-Kendall test modified by effective sample size to detect trend in serially correlated hydrological series. Water Resources Management, 18, 201-218.

(Manuscript accepted 21 February 2015) 